\title{
Factors Influencing Preference for Certification Courses Delivered Through Technology-Driven Distance Education
}

\author{
Ansuman Sar, Satya Narayan Misra
}

\begin{abstract}
As per the Merriam Webster dictionary, the definition of the distance learning is - "It is a method of study where teachers and students do not meet in a classroom but use the Internet, e- mail, video conference, audio conference mediums of the study. The assessments and doubt clearing also happen online and still there are some planned face to face interaction programs with the students." In the late 1900s, correspondence courses started coming into the picture. These courses were mainly introduced for the working professionals and for the people who wish to go for competitive examinations as travelling to the university is difficult if it is far off. This is to enhance the access and reach for the learners. Many of the tutorial companies and coaching centers also use distance learning model to cater to the needs of IIT JEE/Civil services aspirants in India. However, distance-learning courses have much better acceptance in the western countries. In Europe and America, they have wider acceptance and several studies done have proven the need of the distance courses and the perception of the people about the distance courses is really good.
\end{abstract}

Keywords: distance learning, technology-enabled education, online courses, E-learning

\section{INTRODUCTION}

Initially distance courses involved a lot of mail transactions between the faculty and the student. With the technological disruption/interference, the options for distance education have greatly inflated. Long back, as mentioned in the book of Distance-Learning: Principles for Effective Design/Delivery \& Evaluation by C.M. Mehrotra, C. D. Hollister \& L. Mc-Gahey, radios( two way communicating) were used for the teaching. After that, gradually different kinds of technological-delivery instruments were involved in online distance learning. The Examples of these are Cable television/Closed circuit/interactive TV/Audio-visual recordings/Telephones/Mobiles/personal computers and desktops, mobile devices and applications etc. Earlier distance learning was very slow and expensive and it was run or conducted for learners who are at a relatively shorter distance. With the satellites and development of scientific electronics, education-programs were accessed all over the world from any university in any continent. Today, live interaction with the counsellor, live doubt clearing classes and online-proctored assessments are possible with the use of technology innovation and high speed internet. These days considering the rapidly moving world and requirement of multiple skills in profession, access to education and increasing employability, distance-learning courses are in huge demand.

Revised Manuscript Received on August 25, 2019.

Ansuman Sar, Student, Kalinga Institute of Industrial Technology (KIIT), Deemed to be University, Bhubaneswar (Odisha), India

Dr. Satya Narayan Misra, Dean (Academics), Kalinga Institute of Industrial Technology (KIIT), Deemed to be University, Bhubaneswar (Odisha), India.
It is also seen that there is a consistent rise in the number of registrations for these distance courses in India. However, in India it is still not considered as a mainstream education. We hope that with the use of technology, we can increase the effectiveness of the distance education and make this a success. In this research paper, the objective is to find out the main reason for choosing the online courses is and what are the correlations of these reasons with the gender/age and employment status. The brief history of distance education from eighteenth to twentieth century has been tabled below.

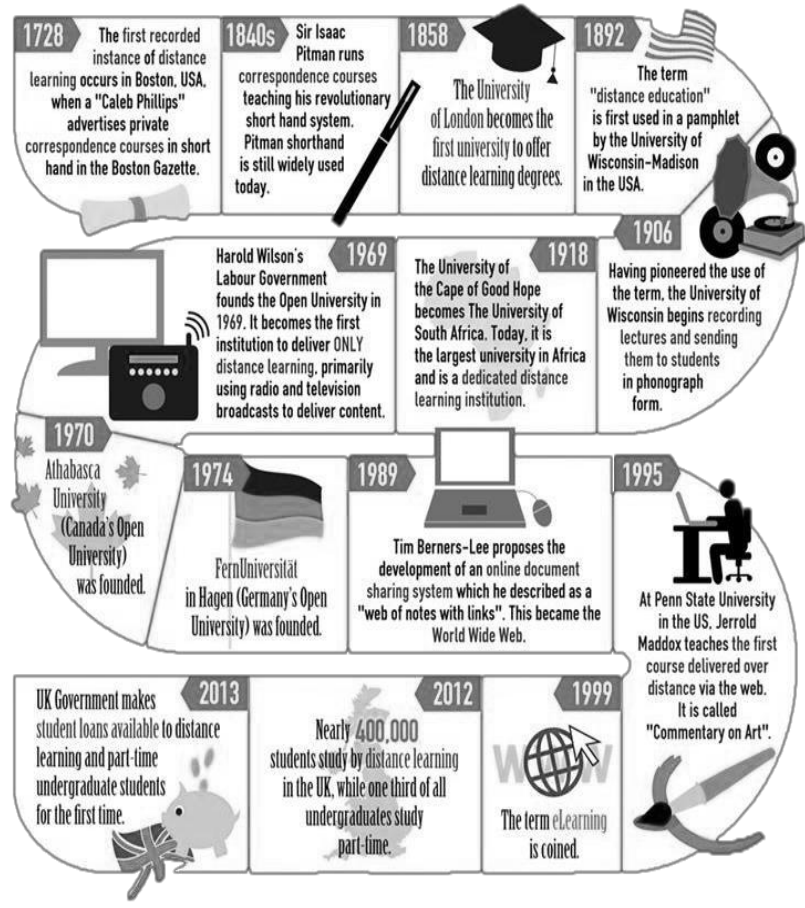

Figure 1.Brief history of distance from 18th to 20th Century (Source: Master Studies, Global trends of Distance learning)

ThereishugeincreaseinthenumberofenrolmentsacrosstheIndia nuniversitiesinthe distance learningcourses.Overaperiodoftime, ithasgrownlikeanything. As perlastyear's statistics shared by Coursera-(world'slargest openeducationprovider):

\section{13 lakhonlinelearners were fromIndia \\ II. Total numberoflearners - 180 Lakhs}

ThenumberofIndianlearners haveincreasedby $70 \%$ innumber.Indiangovernmenttriestoincreasetheregistrationsfo rtheseonlinecoursesandthisis practically not doable by establishing more regular/conventional universities. 


\section{Factors Influencing Preference for Certification Courses Delivered Through Technology-Driven Distance Education}

Theresponse to this is online educationsystem.

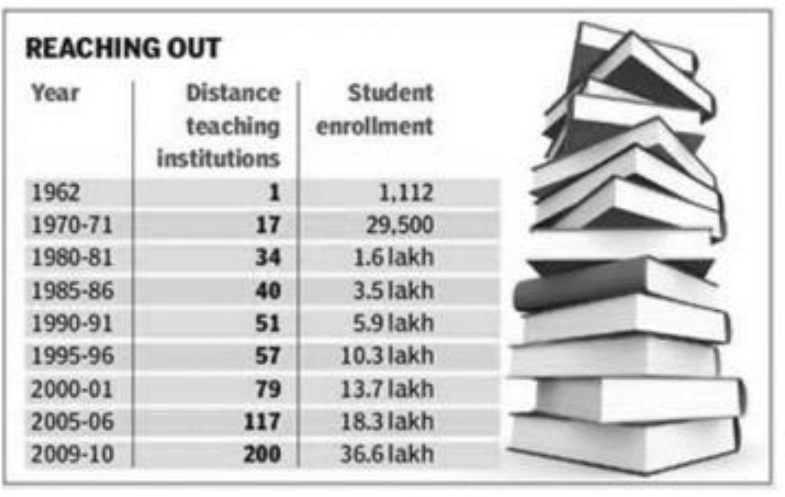

\begin{tabular}{|l|r|r|}
\hline Level & $\begin{array}{l}\text { Regular } \\
\text { enrolment }\end{array}$ & $\begin{array}{l}\text { Distance } \\
\text { enrolment }\end{array}$ \\
\hline Ph.D & 109416 & 136 \\
\hline M.Phil & 24878 & 0 \\
\hline $\begin{array}{l}\text { Post } \\
\text { Graduate }\end{array}$ & 768640 & 1107925 \\
\hline $\begin{array}{l}\text { Under } \\
\text { Graduate }\end{array}$ & 1599953 & 2498983 \\
\hline PG Diploma & 90769 & 68604 \\
\hline Diploma & 183717 & 94247 \\
\hline Certificate & 15083 & 34021 \\
\hline Integrated & 92823 & 1 \\
\hline Total & $\mathbf{2 8 8 5 2 7 9}$ & $\mathbf{3 8 0 3 9 1 7}$ \\
\hline
\end{tabular}

Figure 2. Student enrolment data related to distance education (Source-Ministry of Human Resource Development, Government of India)

Today,notonlygraduationorpost-

graduationdegreesarerequired-weneedalotofskill

enhancement

whichcanhelpusrealtimeforincreasingour

employability. Whiletraditionaldegreeslikeabachelors

ormastersmight bethevalid-proofof youreducationandisrequiredduringinitialscreening.Stilltheyd on'tactuallyfocusontheskills

thatareveryimportantaretheneedofthehour.Hencetheskill-

GAPisfilledbythesewiderange of online -customized courses.Onecanchoosethecoursesas

perhis/herchoice. Thesecoursesarenormallynamedascertificat ecourseornanodegreecourseorskill

enhancementcourse.Thereare examples ofprofessional certificationcourses.

$$
\begin{aligned}
\text { i. } & \text { Awards-certification } \\
\text { ii. } & \text { Certified Developers } \\
\text { iii. } & \text { Googlegivescertificateswhoprovetobeexpertsin } \\
& \text { multipledomains }
\end{aligned}
$$

Nowconsideringthesetrends, it

isprettyunderstoodthatdistanceeducation wouldbean essentialtoolinmeeting theneedsofthepeopleinIndiaand itssuccessand effectivenessifof primeimportant.However,inIndia,itisstillnotthemainstream educationandfacultiesand studentsstill questionits effectiveness. Hence, a research study was carried out to determine, what arethe perceptionsofthepeopleabout thedistancecoursesand howwe enhancethesameusing technology ? There waslimited scope of ourstudyto thestudents only. Thesestudents arefromtheStateOpenUniversity of Odisha, an eastern state of India.Surveyquestionnairehas been used forthesameand51 students' response has been takenwhoaredoing theBasic Computer Knowledge Certification Course through distance mode.

\section{LITERATURE REVIEW}

Educationrequiresapersonalcontactofhighlyqualifiedteacher swiththelearnersasit isasocialactivity.Thedemand foreducationinIndia(whichisoneofthedeveloping nations) hasgone-upas

educationcontinuestobetakenasansignificantbridgebetweens ociety, economicconditions, culturaland politicalscenariosinthis nation.Due to infrastructuraland socio-economicissues, quality educationis not accessibleto all;especiallytothoseinremote

regions.InformationandCommunicationTechnology(ICT)ha sthetremendouspotentialto discardandremove thesebarriersthatarecausingthe problemsoflowereducationalspreadand effectiveness ofeducation.ICTcanactas acatalyst to overcome the belowissues.

i. Cost issuesasthe educationcan be spread throughtechnology/costs dueto distance would beminimized

ii. Lack of faculties(TeachertoStudentratio isverypoor)

iii. Time and distance constraints

iv. Quality oflearning /topicdelivery

As validated byUNESCO (2002), students

of $21^{\mathrm{st}_{\text {century }}}$ would need latest information and communicationtechnologiesintheir educationand learning(acrosstheworld-

poor/developingordeveloped).Newtrendsintechnologyarepl ayingaveryimportant rolein educationsector.National PolicyonInformationandCommunicationTechnologyinSch ool Educationfor the year 2012giveemphasisupontheIC TliteratecommunitysothatallI CT resourcesare used inteachinglearning process.

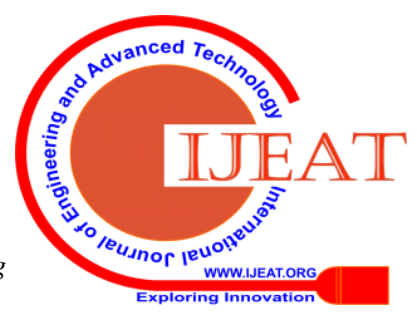


NPICT in School education( National policy on Information and communication technology) stresses upon ICT literate community to use ICT resources in learning /teaching process.

TAM- the Technology Acceptance Model developed by Davis(1989) takes into account of social psychology theory of reasoned action, used for modelling user acceptance of information systems. i. Perceived Usefulness means if you use the system it will increase the task performance

ii. Perceived ease of Use- it should be effortless to use the targeted system

Many research studies say that the perceived usefulness is a substantial determining factor of behavioural intention towards technology. Hence, the user behaviour is explained by Technology Acceptance Model.(Horst et. al. 2007; Venkatesh et. al. 2003)

TAM is based on two major factors-

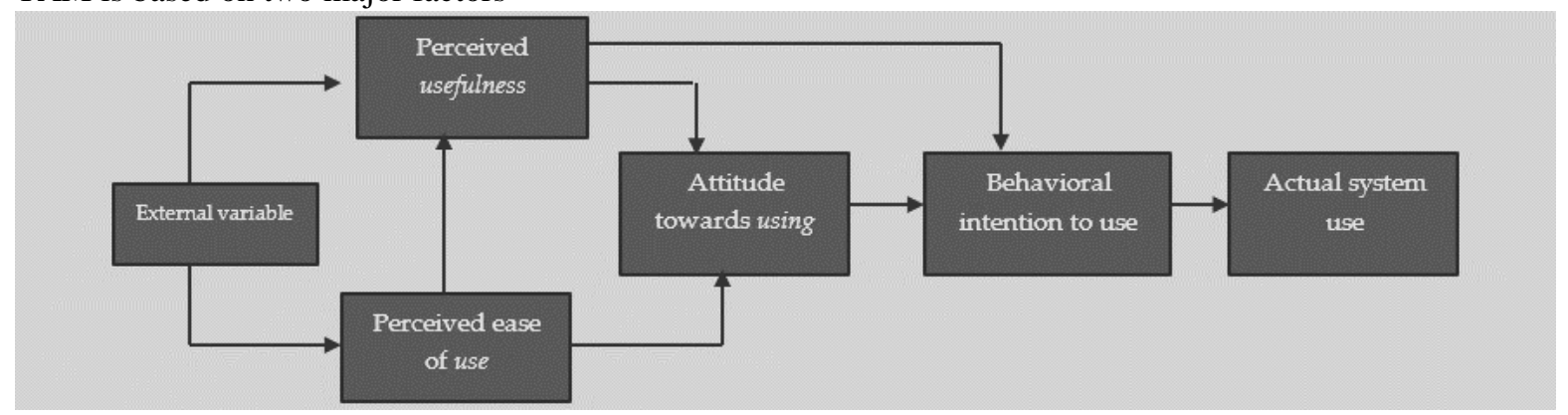

Figure 3.TAM, Source:Perceived Usefulness and IT User Acceptance,Ease of Use Quarterly, 13-3, page no.-339,Davis,

Venkatesh\&Davis(2000)exploitedmoret heTAMmodelandproposedasecondmodel called TAM2. Theyexplainedas below.

- Dependent Variables-Perceived usefulness and usageintentions

- Independent variables - cognitive instrumental processes and social influence process.

Thetheorycanbedepicted asbelow.

The social influence process- It hhighlightsthe impact of three inter-related social forces in selecting or rejecting a technology system-

i. Subjective norm

ii. Voluntariness

iii. Image

Thecognitiveinstrumental processtalks aboutthe individual's job relevanceand quality of theoutput. Foruseracceptanceotherimportant fundamentalfactors are: Results Demonstrability and Perceivedeaseofuse. Unified Theory of Acceptance and Use of Technology (UTAUT) was conceived by Venkatesh(2003). UTUAT is relied upon similarities based on abstract across various TAMs. The theory conveys that IT user acceptance \& usage are explained by four factors viz.Effort Expectancy, Performance Expectancy, Facilitating conditions and Social Influence.(Venkatesh, 2003) Effort expectancy is the degree of comfort or easiness associated with the use of the system. Performanceexpectancy

measurestheindividualbeliefthattheuseofsystemwillhelp theuserinincreasing the task performance. Socialinfluenceis theextenttowhichanindividualperceivesthatitisimportantthat others should alsorecommend forusing thesystem. Facilitating conditions measures the belief that necessary infrastructure are in place in order to helpuseofthesystemforknowledgegains. regardinguseofthe system inthefuture. Usebehaviortalks
Behavioralintentionmeasures theindividual's decision

\section{. (1989).}

about theactual usageof thesystem.

Performanceexpectancyisthemostinfluentialpredictorofinte ntionandremains substantiallyprominent inbothvoluntary and mandatorysettings, during allthe steps ofmeasurement. Effortexpectancyisprominentinbothvoluntaryandmandatory usagecontexts (duringthe beginningstageonly). Social influence is important in volunteer-based contextbut not significant in compulsory circumstances. Facilitating conditions impacts linearly to usage in addition that is explicated by behavioral intentions exclusively. Society of Information Technology is primarily a result of continuing development in new technologies andthe needs ofpeople who use computerScience technologies. In this current era, educational systems seek to prepare teachers and students for the work force and computer literacy becomes so important in all levels of education. ICT reduces time required imparting knowledge. Attitude of students engaged in the class positively influences students' engagement in the class. This also shows that ICT will increase the student engagement in the class. ThisstudyunderstandsICTisessentialinplanningcomput erbasedcourses asresearched andfound.(Mahat, Jamsandekar\& Nalavade,2012)

Indeveloping nations, thetruepotentialofdistanceeducationliesinexpandingacross horizonsandreachingto peopleacrossdemographics(Crooks, 1983).

TheinclusionofDistance

Education in nationalpolicyconsiderationson awiderscalewouldopenuptheprospectof studentshavingtheoptionofchoosingtheircoursesby home tuitionanddistancelearning. Based on the study of various literature, a literature review matrix has been tabled below. 
Factors Influencing Preference for Certification Courses Delivered Through Technology-Driven Distance Education

\begin{tabular}{|c|c|c|c|}
\hline Author \& Year & Topic & Summary & Scope \\
\hline Volery \& Lord, 2000 & $\begin{array}{l}\text { Critical success factors } \\
\text { in online education. }\end{array}$ & $\begin{array}{l}\text { Important components found } \\
\text { are: The instructor } \\
\text { (attitudestowards students, } \\
\text { instructor } \\
\text { competence and classroom } \\
\text { interaction); andthe previous } \\
\text { use of the technology. }\end{array}$ & $\begin{array}{l}\text { Dependency of Online education towards } \\
\text { classical education could have been } \\
\text { explored. }\end{array}$ \\
\hline
\end{tabular}

\section{RESEARCH OBJECTIVES}

Themajorobjectives ofthepresent studyarestated below:

I. To find out the reason for choosing online courses by working and non-working professionals.

II. Gender perceptions and preferences about the Elearning course Basic Computer Knowledge Certification Course and finding outcorrelations ifitexists.

III. To find out theareas whereimprovementisrequiredineLearningin distance mode.

\section{Research Gaps}

The research gaps pertaining to factors influencing the preference for technology-driven distance education are summarized.

The

ContributorsofLearningEffectivenessintechnology-

drivendistancelearningin

India-

NotmuchresearchhasbeendonetofindthisoutinIndia.Inwester

ncountries, the research on

thistopicisprevalent.PerceptionofStudentsaboutcurrenttechno

logyinterventionindistancelearningin Indiaistobe studied-

itwouldalsorevealwhystudentschoosethe distancelearning

coursesand what are themain reasonsbehind it.Genderperceptions towards online or technology-driven distance education.

\section{Hypothesis}

The main hypothesesformulated for the present studyaregiven below:

H1:There is significant relationship betweenthe age of learnerand the reasonforjoining the course

H2: There is significant relationship betweenthe genderof learnerand the reason forjoiningthe course

H3:There is significant relationship

betweentheemployment statusand the reason forjoining thecourse

\section{METHODOLOGY}

In total of 51 Students from Open University of the state of Odisha, a state of India (two distance learning centers namely SAFE and NIAT Computer Education) were the respondents of the survey. They are doing a technology-driven distance education course which is the recognized de-facto standard certification course for IT Literacy certified by the university and delivered through e Learning Mode through its Distance Learning Centers like SAFE and NIAT. Following arethe researchdetails pertaining tothestudy. In this research, Descriptive methodology has been used with convenient sampling as Sampling method. Measuring instrument is Structured Questionnaire with 5-point Likert Scale.

$>$ Researchtype: Descriptive

$>$ Sampling method: Convenient Sampling

$>$ Measuringinstrument :StructuredQuestionnaire

$>$ Scale: 5-point Likert scale

\section{Reliability Test}

Reliabilitytestwasconductedfor32itemsandCronbac

h'salphawasfound to be 0.85 and necessary factor analysis.

The questionswith theLikertratingare selected forthis and otherquestions that don't have quantifiable answersare ignored. (ordinalquestions oropenended questions)

\section{Demographics of sample}

The average age for the group of students comes out to be 23.6 or 24 years. This also includes the assumption that some of the respondents who have not given their age, we have assumed it as zero. This assumption may be correct as we have considered some as outliers and have still included them while calculating. There are respondents who have the age of 30, 35, 37,47, 60 , but mostly people are of the age of 22/23/24 and hence the average age is around 23.6 years. This means most of the students are either Graduates or are going to be the

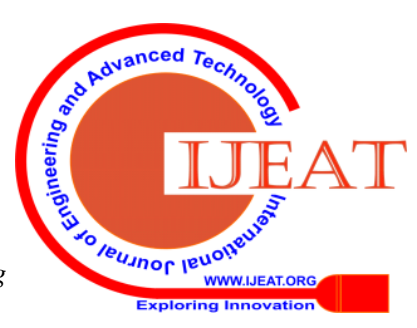


Graduates. (Male: 47\%, Female:53\%). Out of the total respondents - 3 are working( 5.88\%), 47 are not working $(92.15 \%)$ and 1 person is retired( $1.9 \%)$ -

Majority of the students from the sample are not working.

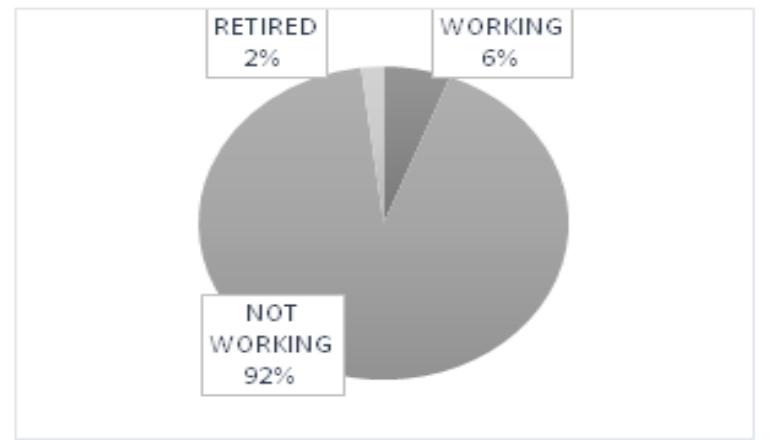

Figure 4. Employment Status of the sample

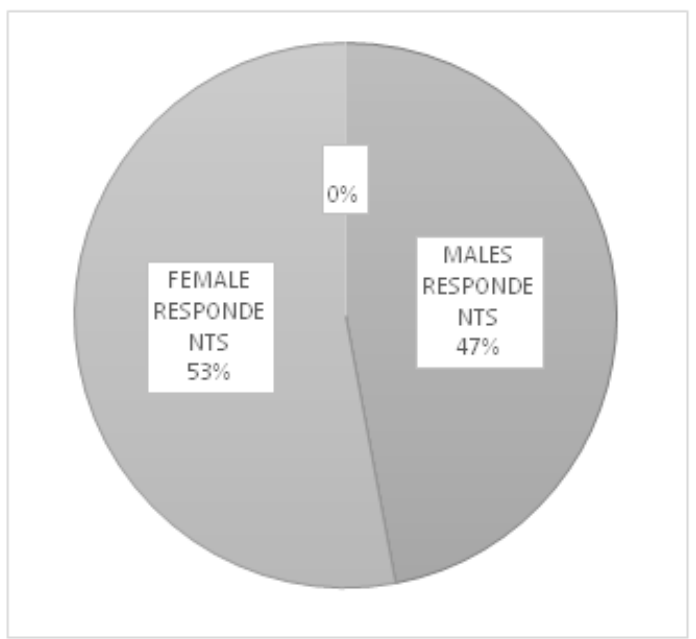

Figure 5. Gender breakup of the sample

TABLE 1: Univariate Analysis

\begin{tabular}{|c|c|c|c|c|c|c|c|}
\hline Particulars & Range & Min. & Max. & M & SE & SD & Variance \\
\hline $\begin{array}{l}\text { Student feedback on E- } \\
\text { learning }(3.1,3.2,4.1,4.2,4.3,4.4,4.5)\end{array}$ & 1.29 & 3.43 & 4.71 & 4.2409 & 0.03699 & 0.26417 & 0.07 \\
\hline Student feedback on technology used in evaluation-7.7 & 5 & 0 & 5 & 4.0196 & 0.15464 & 1.10436 & 1.22 \\
\hline $\begin{array}{l}\text { Student feedback on new technology intervention in } \\
\text { the course }(8.1 \text { to } 8.14)\end{array}$ & 2.14 & 2.36 & 4.5 & 4.084 & 0.04758 & 0.33978 & 0.115 \\
\hline
\end{tabular}

Sample Size $(\mathrm{N})=51$, Mean $=\mathrm{M}, \mathrm{SD}=$ Standard Deviation,

$\mathrm{SE}=$ Standard Error

Overall student feedback on course structure and content is very good - 4.24. Most of them strongly agree or agree.

\section{WORK EXPERIENCE}

Out of 51 people, 46 are not working and only 5 people are working. Out of those 5, 2 people have maximum two years of experience, one person has 3 years and the other person has 6 years of experience. In addition, an outlier has 37 years of experience. So, it is evident that most of the respondents are not working and they have the intentions of getting a job and enhancing their skills to become the employable.

\section{Educational Background}

The majority of the students are graduate students. However, we have almost equal representation from the 12th and post-graduation. Two students have completed their 10th and one student has not completed the 10th class event.

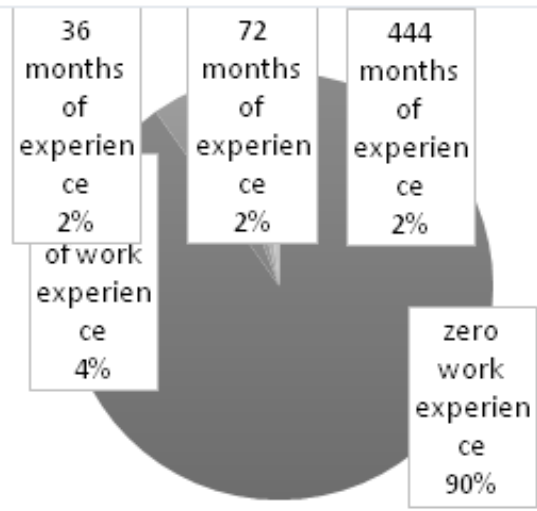

Figure 6. Work Experience Status of the Sample 


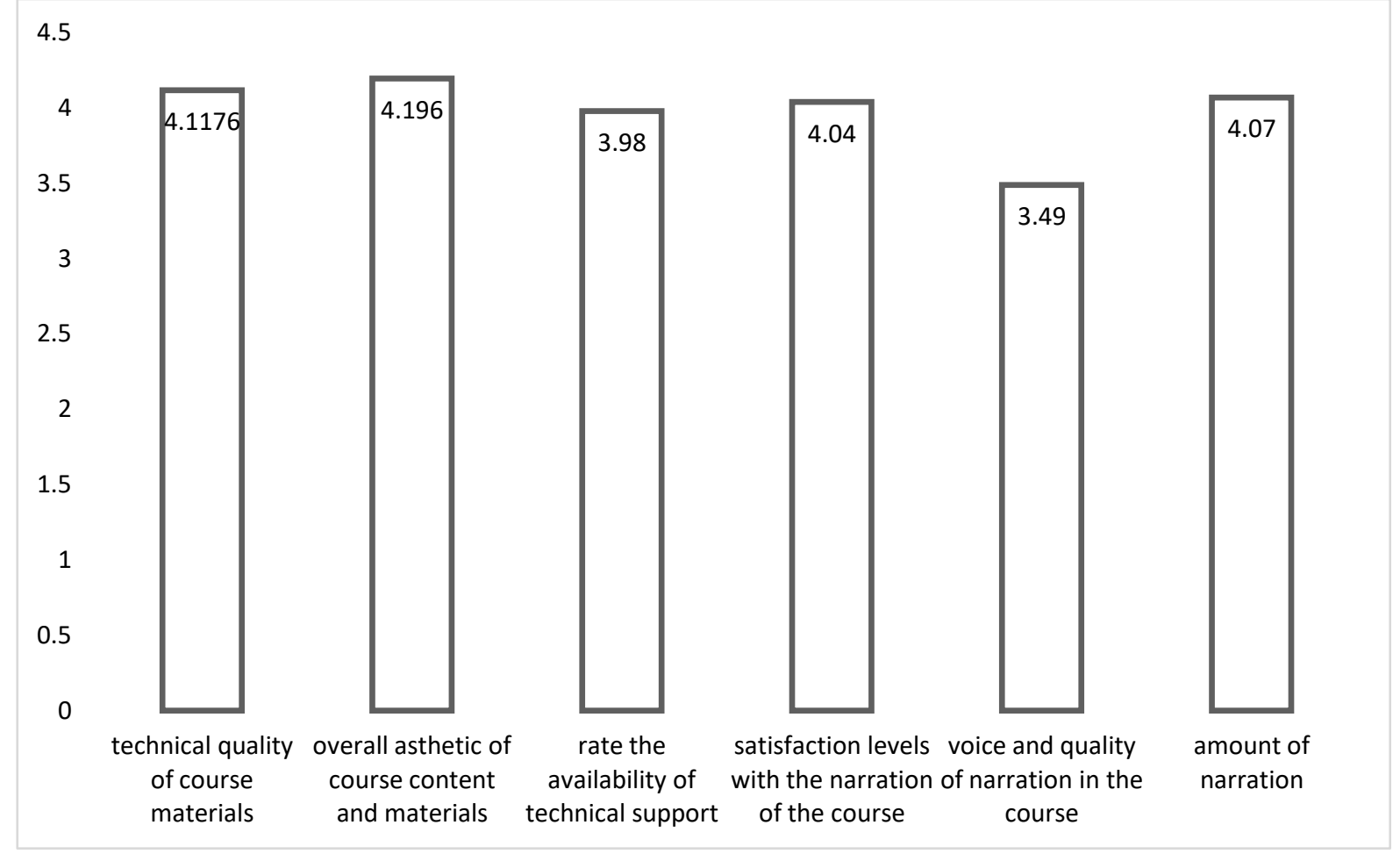

Figure 7. Mean Rating of Students' Feedback

People are satisfied with the overall aesthetic aspect of the course content. Most of the learners have also accepted the fact that the technical quality of course material is good. However, if we go by the rating it becomes evident that the availability of technical support can be improved and this demands for more of counselling and doubt clearing classes by the technically strong faculty. Some of the learners have taken the neutral stand may be because they could not get adequate support for this. Voice and quality of narration (mean 3.49) is not convincing, whereas satisfaction levels with the narration is good as most of the learners have agreed-(this is because of the course content). Variable 3.1 is referred here.

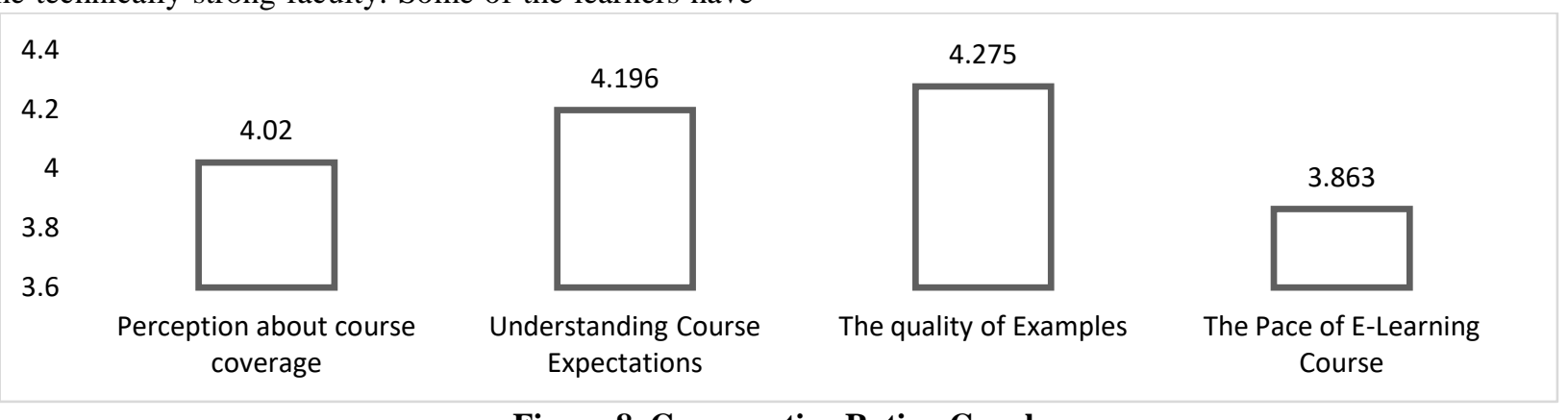

Figure 8. Comparative Rating Graph

From the comparison of Parameters, it is pretty evident that, the Basic Computer Knowledge Certification Course, quality of examples are the highest rated. That also states that the course is interactive and has been accepted well by the students. However, the students just agree or they take a neutral stand regarding the pace of the online learning factor. Probably we need to see that there is appropriate pace in which the course runs so that it will be well interpreted and understood by the students. 


\section{Technology friendliness}

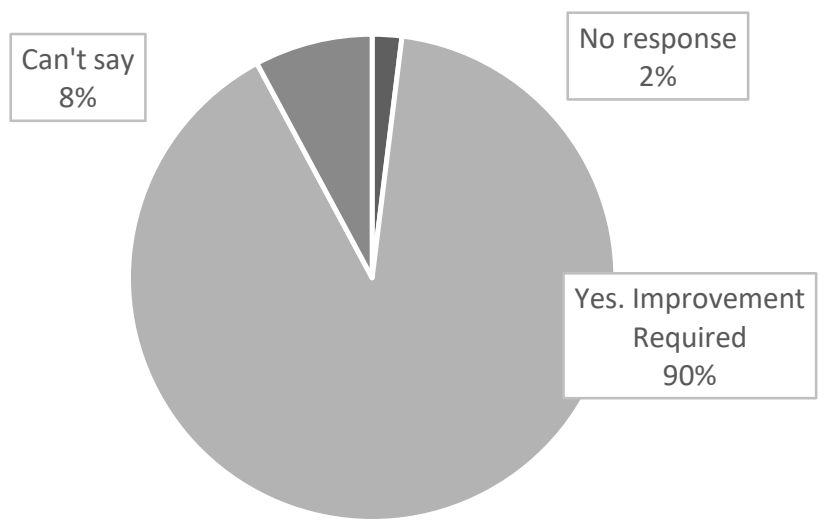

Figure 9. Response based on Technology Friendliness

The backbone of any course is the faculty basefrom the ratings it is evident that, State Open University does not have a good faculty base or set of instructors. $92 \%$ of the learners said that they would expect a better faculty set or instructors for the course. Ease of Access parameter

TABLE 2: BIVARIATE ANALYSIS (CONTINGENCY TABLES for V3 and V51)

\begin{tabular}{|l|c|c|c|}
\hline \multicolumn{5}{|c|}{ Chi-Square Tests( V3 and V51) } \\
\hline \multicolumn{1}{|c|}{ Particulars } & Value & df & Asymptotic Significance (2-sided) \\
\hline Pearson Chi-Square & 7.659 & 3 & 0.054 \\
\hline Likelihood Ratio & 7.915 & 3 & 0.048 \\
\hline Linear-by-Linear Association & 6.066 & 1 & 0.014 \\
\hline N of Valid Cases & \multicolumn{3}{|c|}{51} \\
\hline
\end{tabular}

Interpretation: The chi-square value of 7.659 shows that there is hardly any relationship between the gender and the reason for taking the Basic Computer Knowledge Certification Course .

The bivariate analysis between gender and reasons for joining:

TABLE 3: BIVARIATE ANALYSIS (CONTINGENCY TABLES for V2 and V51)

\begin{tabular}{|l|c|c|c|}
\hline Particulars & Value & df & $\begin{array}{c}\text { Asymptotic Significance (2- } \\
\text { sided) }\end{array}$ \\
\hline Pearson Chi-Square & $86.107^{\mathrm{a}}$ & 51 & 0.002 \\
\hline Likelihood Ratio & 81.506 & 51 & 0.004 \\
\hline $\begin{array}{l}\text { Linear-by-Linear } \\
\text { Association }\end{array}$ & 9.472 & 1 & 0.002 \\
\hline N of Valid Cases & \multicolumn{3}{|c|}{51} \\
\hline
\end{tabular}

In SPSS- Variables are V3(Gender) and V51 (Reason for registering the course)

\section{Interpretation:}

$\begin{aligned} \text { i. } & \text { Employability } \\ \text { ii. } & \text { Skill enhancement } \\ \text { iii. } & \text { Requirement in the present job } \\ \text { iv. } & \text { Out of interest } \\ \text { v. } & \text { Others }\end{aligned}$

The chi-square value of 86.107 shows that there is $\mathrm{A}$ STRONG relation between the AGE and the reason for taking the Basic Computer Knowledge Certification Course .Bivariate Analysis between employment status( working and not working) and the main reason for taking the distance learning course- V5 and V51.

TABLE 4: Correlation Table

\begin{tabular}{|l|l|l|l|l|l|}
\hline Particulars & & $\mathrm{V} 51$ & $\mathrm{~V} 2$ & $\mathrm{~V} 3$ \\
Retrieval Number F9051088619/2019@BEIESP & Published By: \\
DOI: $10.35940 /$ ijeat.F9051.088619 Eyes Intelligence Engineering \\
\& Sciences Publication
\end{tabular}


Factors Influencing Preference for Certification Courses Delivered Through Technology-Driven Distance Education

\begin{tabular}{|c|c|c|c|c|c|}
\hline \multirow{4}{*}{ Pearson Correlation } & V51 & 1.000 & 0.435 & 0.348 & -0.028 \\
\hline & V2 & 0.435 & 1.000 & 0.063 & 0.031 \\
\hline & V3 & 0.348 & 0.063 & 1.000 & 0.098 \\
\hline & V5 & -0.028 & 0.031 & 0.098 & 1.000 \\
\hline \multirow[t]{4}{*}{ Sig. (1-tailed) } & V51 & & 0.001 & 0.006 & 0.422 \\
\hline & V2 & 0.001 & & 0.329 & 0.414 \\
\hline & V3 & 0.006 & 0.329 & & 0.246 \\
\hline & V5 & 0.422 & 0.414 & 0.246 & \\
\hline \multirow{4}{*}{$\mathrm{N}$} & V51 & 51 & 51 & 51 & 51 \\
\hline & V2 & 51 & 51 & 51 & 51 \\
\hline & V3 & 51 & 51 & 51 & 51 \\
\hline & V5 & 51 & 51 & 51 & 51 \\
\hline
\end{tabular}

ThePvalueof0.157whichis greaterthan 0.05 means thereisnot significantrelationship betweentwo

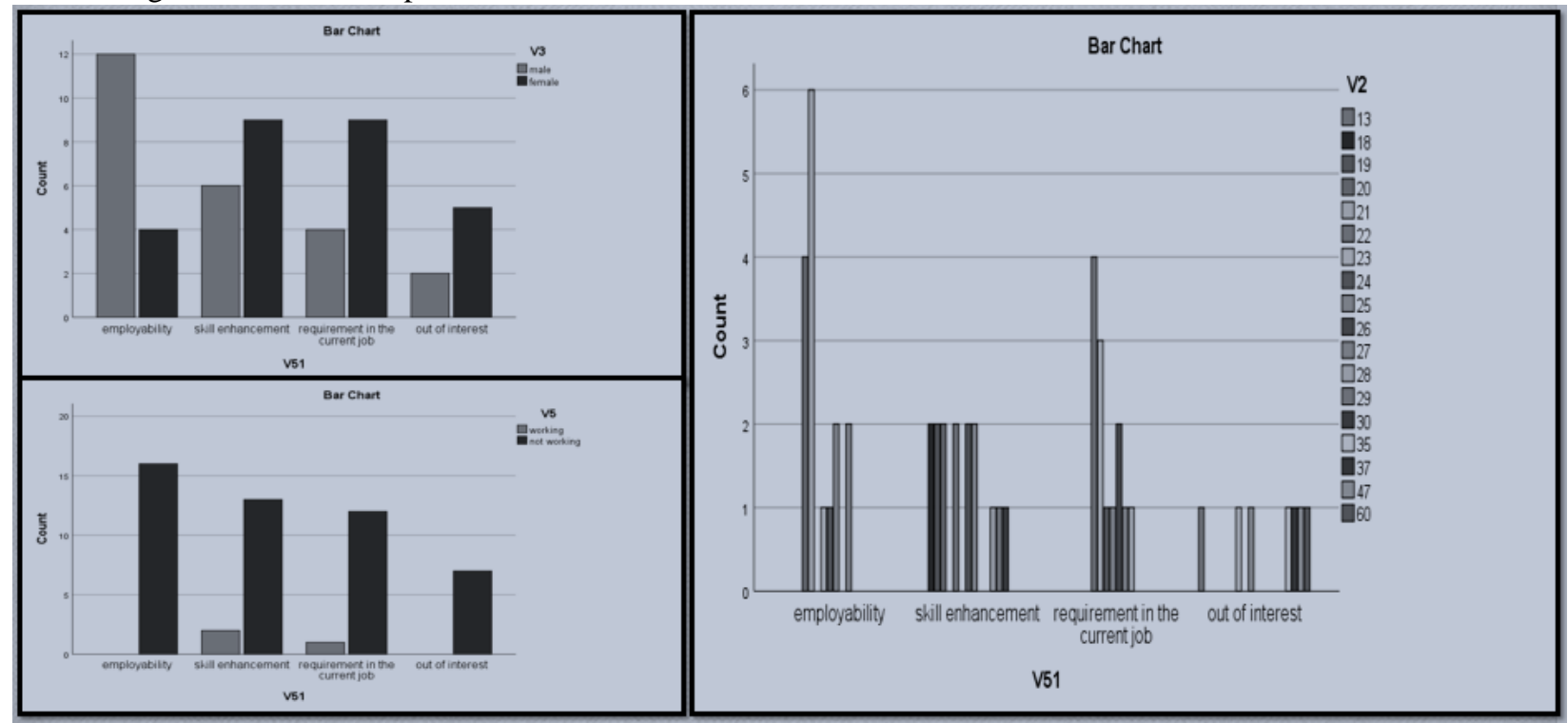

Description of Variables:

> V2-Age, V3-Gender, V5-Working/Not Working, V51- Main reason for joining the Basic Computer Knowledge Certification Course .

$>$ Dependent Variable- V51.

$>$ Independent Variable- V2,V3,V5

\section{Interpretation}

> V51 has maximum correlation with V2 ( age) which is supported by bivariate analysis too. However - it is negatively correlated to V5.

$>$ Positive correlation between the reason for registering for the Basic Computer Knowledge Certification Course and age - 0.435 positive correlation between age and reason for doing Basic Computer Knowledge Certification Course - .348. variables-thisis alsosupported bythelow chi squarevalue of 9.314 .

Figure 10. Graphical representation of Bi-variate analysis

$>$ Zero or little Negative correlation between the employment status and reason for choosing the course

From the above study, hypothesis H1 is accepted and H0 is rejected which means there is significant relationship between age and reason for joining the course. Hypothesis $\mathrm{H} 2$ is rejected and the null hypothesis is accepted. This implies there is no significant relationship between Gender and reason for joining the course. Hypothesis H3 is rejected and the null hypothesis is accepted connoting that, there is no significant relationship between employment status and reason for joining the course.

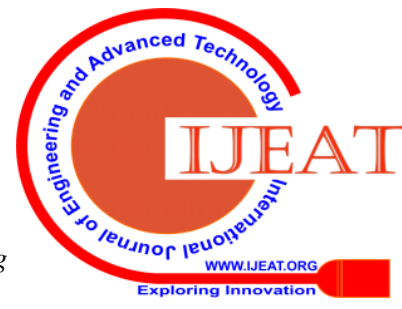




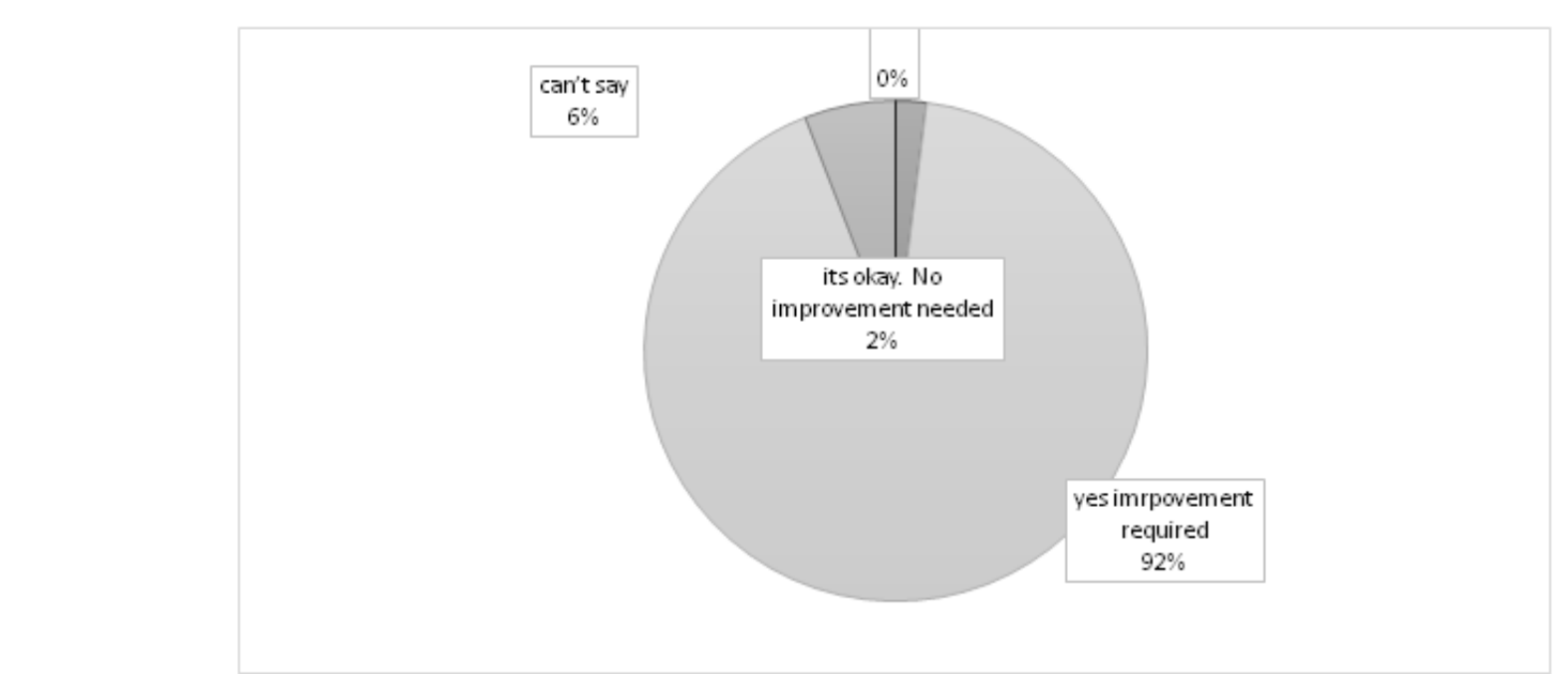

\section{SUMMARY OF SUBJECTIVE FEEDBACK \\ $43.14 \quad$ ofthe respondents suggested}

Figure 11. Improvement suggested w.r.t. Good instructor / Faculty improvementrequiredinevaluation pattern.13.72\% of respondents indicated that, the duration of the Basic Computer Knowledge Certification Course which is 3 months at present needs to be increased to at least 4 months.Rest respondents indicated no improvement required in the course.

\section{SCOPE AND LIMITATIONS OF THE STUDY}

Further study can be done on other Open Universities in other Indian states and make a comparison (KSOU, Symbiosis distance University, Sikkim Manipal etc.) with State Open University. Studies also may be done for long term courses as well and try to find out how technology implementation increases their enrolment. The survey for the present study was conducted for 51 students only as the time was limited. We could have gone for more number of students with more number of courses. Personal interaction with the respondents and more of qualitative research can be done.

\section{CONCLUSION}

Integration of Technology is University Courses in India is still at very nascent stage. From the study, it is found that, students expect human touch along with technology-driven learning for facilitation. However, overall feedback on course was good but some students indicated for improvement in Evaluation pattern. The findings of the study may be useful to administrators and higher education planners at national level and state level for formulating correct policies and strategies with regard to the modernization and application of Information Technology to meet the rising educational needs.

\section{REFERENCES}

1. Albirini, A. (2004, August 18). Teachers' attitudes toward information and communication technologies: the case of Syrian EFL teachers. Elsevier. Retrieved from www.elsevier.com/locate/compedu

2. Alharbi, A. M. (2013). Teacher's Attitudes towards Integrating Technology: Case Studies in Saudi Arabia and the United States. Thesis, Grand Valley State University. Retrieved from http://scholarworks.gvsu.edu/theses

3. Alkana, F., \& Erdema. (2010, January 12). The attitudes of student teachers towards educational technologies according to their status of receiving teaching application lessons. Procedia Social and Behavioral Sciences, 2523-2527. Retrieved October 30, 2017

4. Ang'ondi, E. K. (2013, July 2-5). Teachers Attitudes and Perceptions on the Use of ICT in Teaching and Learning as Observed by ICT Champions. World Conference on Computers in Education, (pp. 2128). Mombasa. Retrieved from https://www.scribd.com/document/231113091/V1-3-100-AngodifullR-FPR

5. Banas, J. R. (2010). Teachers' Attitudes toward Technology: Considerations for Designing Preservice and Practicing Teacher Instruction., (pp. 114-127). Illinois. Retrieved from http://dx.doi.org/10.1080/02763911003707552

6. Bhattacharya, I., \& Sharma, K. (2007). India in the knowledge economy - an electronic paradigm. International Journal of Educational, 543-568.

7. Breedt, M. (2015). Aspects influencing accounting teachers' attitude towards Computer Aided Learning. Pretoria.

8. Brown, H. (2014, May 14). Teachers Attitudes and Confidence in Technology Integration. Marshall Digital Scholar. Retrieved October 30, 2017, from http://mds.marshall.edu/etd

9. Caliskan, S., Suzek, S., \& Ozcan, D. (2017). Determining student satisfaction in distance education courses. Procedia, 529-538.

10. Chitlangia, A. K., \& Agarwal, S. (2013). Distance Education: Opportunity and Challenges. Anusandhanika, 66-73.

11. Crooks, S. (1983). Distance Education and the Developing World. European Journal of Education, 329-343.

12. Fanai, L., \& Chhangte, R. (2016, August). A study of the attitude of the secondary school teachers towards ICT with Respect to teaching experience and professional qualification. International Journal of Engineering Science and Computing, 6(8), 2878-2880.

13. Farahani, M. F. (2012). Ethics principles in distance education. Procedia Social \& Behavioral Sciences, 890-894.

14. Farida Umrani-Khan, F., \& Iyer, S. (n.d.). ELAM: A Model for Acceptance and Use of E-learning by Teachers and Students. Research Paper, Indian Institute of Technology Bombay, Department of Computer Science and Engineering, Mumbai.

15. Ganesan, P., \& Krishnakumar, R. (2016, May). Attitude of teacher educators towards ICT. International Journal of Research, Granthaalayah, 4(5), 7-11. Retrieved from www.granthaalayah.com

16. Gregori, P., Martínez, V., \& Moyano-Fernández, J. J. (2017). Basic actions to reduce dropout rates in distance learning. ScienceDirect, 48-52.

17. Haseentaj, \& M, P. (2017). Attitude of Chamarajanagara District (India) Secondary School Teachers towards Using New Technology. Imperial Journal of Interdisciplinary Research (IJIR), 3(4), 37-42. Retrieved October 2017, from http://www.onlinejournal.in

18. Howley, A., Wood, L., \& Brian, H. (2011). Rural elementary school teachers' technology integration. Journal of Research in Rural Education, 1-13.

19. KILINC, E., \& KILINC, S. (2016, June 14). Teachers' attitudes toward the use of technology in social studies teaching. Research in Social Sciences and Technology, 59-76.

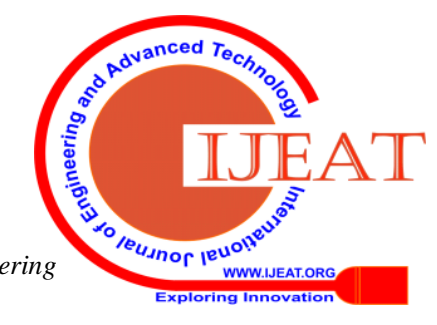




\section{Factors Influencing Preference for Certification Courses Delivered Through Technology-Driven Distance Education}

20. Kyriakidou, M., Chrisostomou, C., \& Banks, F. (1999, September 22 25). Primary Teachers' Attitude to the Use of ICT: a comparative study between Cyprus and the UK. (E. Line, Producer) Retrieved October 31, 2017, from http://www.leeds.ac.uk/educol: http://www.leeds.ac.uk/educol/documents/00001300.htm

21. Luaran, E., Danial, A., Ghazali, M., \& Jain, J. (2014). ICT integration in classrooms: the educators' perspective based on their school and home ICT use . ESTEEM Academic Journal, 66-74.

22. Mahat, S., Jamsandekar, P., \& Nalavade, K. (2012). A study of teachers' attitude towards ICT in Education. International Journal of Information Technology and Knowledge Management, 93-97.

23. Mohd Ayub, A. F., Abu Bakar, K., \& Ismail, R. (2015). Factors predicting teachers' attitudes towards the use of ICT in teaching and learning.

24. Morrisa, D. (2009, December 10). Are teachers technophobes? Investigating professional competency in the use of ICT to support. Procedia - Social and Behavioral Sciences, 4010-4015. Retrieved October 28, 2017, from http://www.sciencedirect.com

25. Mukerji, S., \& Tripathi, P. (2005). quality education in india: a mission revisited for distance education institutions. Asian Association of Open Universities Journal, 45-51.

26. Muthomi, M. W. (2014). Reactions of schools' head teacher toward computer use in teaching and learning in secondary schools in tharaka-nithi county in kenya. International Journal of Information Science and Education, 3(1), 7-14. Retrieved from www.ripublication.com

27. Nair, I., \& Das, V. M. (2012, March). Using Technology Acceptance Model to assess teachers' attitude towards use of technology as teaching tool : A SEM Approach. International Journal of Computer Applications, 42(2), 1-6.

28. Ó Buachalla, S. (1989). Distance Education as an Element of Policy. European Journal of Education, 73-78.

29. Oldfield, A. (2010). A summary of teacher attitudes to ICT use in schools. Futurelab. Innovative Technologies for Engaging Classrooms (iTEC). Retrieved October 31, 2017

30. Padmavathi, M. (2013, November). A Survey of Secondary School Teachers' Perceptions, Competency and Use of Computers. International Journal of Education and Psychological Research (IJEPR), 2(4), 7-16.

31. Panigrahi, G., Das, A., \& Basu, K. (2011). A study to increase effectiveness of distance learning websites in India with special reference to the state West Bengal to increase the present GER of higher education through incorporation of $E$ learning facility in a better way. Procedia Social \& Behavioral Sciences, 1535-1539.

32. Paul, A. A. (2016). Higher secondary teachers attitude towardsthe use of ict in teaching learning process. IERJ, 2(7), 1-2. Retrieved October 2017

33. Redmond, P., \& Brown, K. (2004, March). Are We There Yet? The Journey of ICT Integration. International Journal of Science and Research, 1-8

34. Sabzian, F., \& Gilakjani, A. P. (2013, January 13). Internationa Journal of Applied Science and Technology, Integration, Experience, Anxiety, and Literacy in English Language Teaching and Learning. International Journal of Applied Science and Technology, 3(1), $67-$ 75.

35. Salleh, S. (2015, October 25). Examining the influence of teachers' beliefs towards technology integration in classroom. The International Journal of Information and Learning Technology, 33(1), 17-35. Retrieved from www.emeraldinsight.com/2056-4880.htm

36. Sanchez, A., \& Marcos, J. (2012). In Service teachers' attitude towards the use of ICT in the Classroom. Procedia - Social and Behavioral Sciences, 1358-1364. Retrieved October 2017, from www.sciencedirect.com

37. Shirvani, H. (2014, April). Pre-service teachers' attitudes toward using technology in schools. Journal of Literacy and Technology, 15(1).

38. Singh, K. S. (2012, July 12). Teachers' Attitude Towards Information and Communication Technology. Shodh Sanchayan, 2(2), pp. 1-4. Retrieved October 30, 2017, from www.shodh.net

39. Teachers' Attitude and Competence Towards the use Of ICT Resources: A Case Study Of University Of Agriculture Lecturers, Abeokuta Ogun State, Nigeria. (2013). The Information Manager, $13(1 \& 2)$.

40. Verma, A. (2016). Distance Learning Systems of in India. Splint International Journal of Professionals, 116-122.

41. Yadav, R. (2015). Attitude of secondary school teachers towards the use of information communication technology in education International Journal of Education and Information Studies, 31-33.

\section{First Author details}

Ansuman Sar, Student, Kalinga Institute of Industrial Technology (KIIT), Deemed to be University, Bhubaneswar (Odisha), India.

Mr. Ansuman Sar has experience of more than six years in Socia Project Management. He is doing his Ph.D. at KIIT School of Management $(\mathrm{KSoM})$. His area of research is 'ICT in Education'. He did B. Tech. in Computer Science \& Engineering and pursued Post Graduate Program leading to Degree in Management. Presently, he is working as Program Manager at Odisha Knowledge Corporation Limited, a special purpose vehicle under Higher Education Department, Government of Odisha. He is proficient in executing community development and social programs involving planning, operational analysis of policy framework and execution. He has expertise in improving Techno-Education System and spearheading Government Projects including PPP projects in e-Governance sectors. He has orchestrated development in rural arears of Odisha by implementing ICT@Schools project and boosted IT based education on a Build Own Operate Transfer (BOOT) basis. He has used innovative method of teachers' training developing situational-based training modules in the form of episodes telecasted as television serial on Doordarshan Odia. $\mathrm{He}$ has built e Content in Odia for 9th and 10th Standard. He has identified and motivated the young entrepreneurs of Odisha, built their capacities for spreading IT Literacy as well as Skill development programs in order to bridge the Digital Divide among the masses and promoting Digital Citizenship.

\section{Second Author details}

Dr. Satya Narayan Misra, Dean (Academics), Kalinga Institute of Industrial Technology (KIIT), Deemed to be University, Bhubaneswar (Odisha), India.

Prof. S.N.Misra, did his MA in Applied Economics with Internationa Trade and Statistics as his special papers with first class. He did his Ph.D. (Economics) on "Challenges, Before Self-Reliance in Critical Defense Technology", a pioneering area on the subject. Initially he was the Indian Economics Service (1976-79) when he did Cost Benefit Analysis of World Bank Projects and handled International Development Agency (IDA) desk Thereafter, he was an Officer in the Indian Defense Accounts Service (1979-2012), when he served as Director (Finance) with DRDO, Financial Advisor and Joint Secretary to Indian Air Force \& JS (Aero Space). He authored the Defense Procurement Manual (2005), drawing encomiums for the Prime Minister's Office. Before voluntary retirement in 2012, he was Principal Controller of Defense Accounts (Navy) \& PCDA (Southern Command) in the rank of Addl. Secretary to Govt. of India. He was trained in IRBM, California, Defense Acquisition University, Washington, Marshall Institute of Strategic Studies, Munich, IIMs, Calcutta and Bangalore. 